\title{
Quality of Life, Participation, and Functional Status in Cerebral Palsy: A 13-year Follow-up Study
}

\section{Serebral Palside Yaşam Kalitesi, Katılım ve Fonksiyonel Durum: 13 Yıl Takip Çalışması}

\author{
(D) Bilinc DOGRUOZ KARATEKIN1, (1) Afitap ICAGASIOGLU2
}

Istanbul Coztepe Prof. Dr. Suleyman Yalcin City Hospital, Clinic of Physical Medicine and Rehabilitation, Istanbul, Turkey

2Istanbul Medeniyet University Faculty of Medicine, Department of Physical Medicine and Rehabilitation, Istanbul, Turkey

\begin{abstract}
Objective: This study aimed to investigate the current status and changes in motor and functional status, participation, and quality of life of individuals with cerebral palsy (CP) during the 13-year follow-up. Methods: Data from the database were retrospectively analyzed, including comorbidities, mobility status, orthotic usage, and information about the rehabilitation program and follow-up. The EuroQol 5-Dimension 3-Level (EQ-5D-3L) was used to measure the health-related quality of life.

Results: Of our participants, $38.4 \%$ could independently walk 13-years ago, which increased to $51.2 \%$ presently. The orthotic usage decreased from $48.7 \%$ to $25.6 \%$, and the rate of continuing rehabilitation decreased from $100 \%$ to $58.9 \%$. The mean EQ-5D-3L score was $0.36 \pm 0.42$, and the mean EQ-visual analog scale score was $68 \pm 24$.01.

Conclusions: Individuals with CP and their caregivers should be aware that $C P$ is a lifelong disease and their continuity in rehabilitation programs should be encouraged. Independence in daily life activities should be aimed and participation in social life should be ensured.

Keywords: Cerebral palsy, quality of life, disability, participation
\end{abstract}

\begin{abstract}
öz
Amaç: Serebral palsili (SP) bireylerin 13 yıllık izlem süresince fonksiyonel durum, katılım ve yaşam kalitelerindeki değişimin araştırılması amaçlanmıştır.

Yöntemler: Geçmiş veriler veritabanından elde edildi. Komorbiditeler, mobilite durumu, ortez kullanımı, rehabilitasyon programı ve izlem bilgileri sorgulandı. Sağlıkla ilişkili yaşam kalitesini ölçmek için EuroQol 5-Dimension 3-Level (EQ-5D-3L) kullanıldı.

Bulgular: On üç yıl önce katılımcıların $\% 38,4$ 'ü bağımsız yürüyebiliyorken, günümüzde bu oran \%51,2'ye yükselmişti. Ortez kullanımının \%48,7'den \%25,6'ya, rehabilitasyona devam etme oranının \%100'den \%58,9'a düştüğü tespit edildi. Ortalama EQ-5D-3L skoru 0,36 $\pm 0,42$, ortalama EQ-vizüel analog skala skoru $68 \pm 24,01$ idi.

Sonuçlar: SP'li bireyler ve bakım verenlerinde, SP'nin ömür boyu süren bir hastalık olduğu farkındalığı yaratıımalı ve rehabilitasyon programlarına devamlılıkları teşvik edilmelidir. Günlük yaşam aktivitelerinde bağımsızlık hedeflenmeli, sosyal yaşama katılımları sağlanmalıdır.

Anahtar kelimeler: Serebral palsi, yaşam kalitesi, disabilite, katılım
\end{abstract}

\section{INTRODUCTION}

Cerebral palsy (CP) is a non-progressive loss of motor function, posture, and movement that restricts the movement due to lesion or injury in the developing brain in the intrauterine period or the first months of life. In these patients, secondary medical problems, such as epilepsy, mental retardation, behavioral disorders, swallowing problems, and musculoskeletal disorders, are seen'. Mainly, with the inadequacy of movement skills, it is an important developmental disorder that causes disability in speaking, learning, independence, and participation.

$\mathrm{CP}$ is defined as a static motor deficiency; however, it dynamically changes with the development and aging process ${ }^{2}$. The follow-up evaluations of persons who reached adulthood should be continued for the occurring

Address for Correspondence: B. Dogruoz Karatekin, Istanbul Goztepe Prof. Dr. Suleyman Yalcin City Hospital, Clinic of Physical Medicine and Rehabilitation, Istanbul, Turkey

E-mail: bilincdogruoz@hotmail.com ORCID ID: orcid.org/0000-0002-0568-9498

Received: 08 January 2022

Accepted: 02 February 2022

Online First: 15 February 2022

Cite as: Dogruoz Karatekin B, Icagasioglu A. Quality of Life, Participation, and Functional Status in Cerebral Palsy: A 13-year Follow-up Study. Medeni Med J 2022;37:105-112

${ }^{\circledR}$ Copyright 2022 by the Istanbul Medeniyet University / Medeniyet Medical Journal published by Galenos Publishing House.

Licenced by Creative Commons Attribution-NonCommercial 4.0 International (CC BY-NC 4.0) 
changing needs and additional problems. Monitoring the health status of patients in the long-term is necessary to meet their changes.

$C P$ is a lifelong condition that cannot be fully corrected, thus its treatment is focused on preventing or minimizing deformities and increasing the capacity to participate in home and community activities. The literature revealed that in Turkey a high majority of these individuals cannot complete their education, are unemployed, and are dependent on their families ${ }^{3}$. However, Murphy et al. ${ }^{4}$ revealed that the percentage of employment even for more severe patients increased with improved rehabilitation technologies and home support services, and more patients are independently living. Additionally, Hutchison ${ }^{5}$ revealed that $88 \%$ of the college graduates were employed.

Long-term follow-up evaluations of individuals with $C P$, whose rehabilitation lasts for life, are mostly disrupted as they reach adulthood. Long-term follow-up studies in these patients are limited and mostly restricted to northern countries ${ }^{6-8}$.

In this study, 100 individuals with CP who were followed up 13 years ago were contacted by phone, and their current motor, functional, and social status, quality of life (QoL), and participation were investigated.

\section{MATERIALS and METHODS}

\section{Participants}

Of the 100 patients, 43 were reached by phone and has data in the system 13 years ago, thus were included in the study. Research ethics approval was obtained from Istanbul Medeniyet University Goztepe Training and Research Hospital Clinical Research Ethics Committee (decision no: 2020/0025, date: 05.02.2020). All caregivers gave verbal informed consent.

\section{Measures}

Past mobility status, comorbidities, rehabilitation program, and orthotic usage were obtained from patient files.

The demographic information (gender, age, and accommodation, educational, and employment status), CP type, comorbidities, mobility status (walking independently, walking with help or orthosis, and unable to walk), orthotic usage, and information on their continuing rehabilitation program and regular doctor follow-up were evaluated.

Participants were questioned if they could perform various daily life activities (TV remote, computer keyboard, mobile phone, dressing up, eating, toilet, and bath) to assess their independence and participation in daily life activities. Going out independently and going out dependently, and its frequency was evaluated.

The EuroQol 5-Dimension 3-Level (EQ-5D-3L) was used to measure health-related quality of life (HRQoL). The EQ-5D-3L is a generic measure of HRQoL that is used worldwide? . The scale evaluates five subdomains, including mobility, self-care, usual activities, pain/ discomfort, and anxiety/depression, at three levels. The utility value associated with each health state is calculated using the UK value set and values vary between 0 (being dead) and 1 (being in perfect health). Traditionally, UKbased value sets were used. The value sets are based on the preferences of individuals in a general population for whom their health status is defined ${ }^{10}$. Many countries have created their value sets in recent years" ${ }^{11}$. Scale validity and reliability were performed in patients with acute coronary syndrome by Kahyaoğlu Süt and Ensar ${ }^{12}$. EQ-5D-3L scale is used as the HRQoL scale in many CP studies worldwide $\mathrm{e}^{13-15}$. The EQ-visual analog scale (VAS) is a scale in which a person scores their health status from 0 (worst imaginable health) to 100 (best imaginable health) on a vertically oriented graph grade scale.

\section{Procedure}

This case-control study was conducted using a questionnaire prepared for the relatives of patients who were reached by phone.

\section{Statistical Analysis}

Statistical analysis was conducted using the Statistical Package for the Social Sciences Version 22.0 (SPSS Inc., Chicago, IL, USA). Descriptive values for numerical demographic and clinical data were computed as mean \pm standard deviation (minimum-maximum) and frequency (number and percent) for categorical variables. The Wald test was used to compare two groups, and the One-Way Analysis of variance model was used to compare more than two groups concerning numerical variables. Results were evaluated using the two-tailed test with statistical significance set at $p$-values of $<0.05$ and $<0.01$.

\section{RESULTS}

Forty-three participants who had a follow-up file 13 years ago were reached by phone. The mean age was $19.23 \pm 6.47$ years. Of the participants, 17 were females (39.5\%) and 26 were males (60.5\%). Four individuals, whose caregivers were reached, died for various reasons. The distribution of CP subtypes, accommodation, 
educational, and working status of the participants are presented in Table 1.

Of the participants, 30 (69.7\%) had mental problems, $25(58.1 \%)$ had speech problem, $22(51.1 \%)$ had sensory problems, 17 (39.5\%) had epilepsy, 12 (27.9\%) had

\begin{tabular}{|l|l|l|}
\hline \multicolumn{3}{|l|}{ Table 1. CP subtypes and demographic data. } \\
\hline \multicolumn{3}{|l|}{ n } \\
\hline CP subtype & 12 & 27.9 \\
\hline Spastic unilateral & 29 & 67.4 \\
\hline Spastic bilateral & 1 & 2.3 \\
\hline Dyskinetic & 1 & 2.3 \\
\hline Mixed & \multicolumn{2}{l|}{} \\
\hline Accomodation status & 38 & 97.4 \\
\hline With family & 1 & 2.5 \\
\hline With partner & \multicolumn{2}{|l|}{} \\
\hline Education status & 13 & 33.3 \\
\hline Illiterate & 3 & 7.6 \\
\hline Literate & 10 & 25.6 \\
\hline Special education & 7 & 17.9 \\
\hline Primary school & 5 & 12.8 \\
\hline High school & 1 & 2.5 \\
\hline University & \multicolumn{2}{|l}{} \\
\hline Working status & 37 & 94.8 \\
\hline Unemployed & 1 & 2.5 \\
\hline Part-time & 1 & 2.5 \\
\hline Full-time & \multicolumn{2}{|l|}{} \\
\hline CP: Cerebral palsy & \multicolumn{2}{l}{} \\
\hline
\end{tabular}

bladder/bowel problems, 11 (25.5\%) had gastrointestinal/ nutritional problems, and 7 (16.2\%) had respiratory problems.

Participants' mobility status, orthotic use, and past and present rehabilitation program attendance are presented in Table 2. The distribution of the participants' mobility status 13 years ago and today according to the CP subtypes is shown in Figure 1.

Of the patient who continued rehabilitation, 12 (52.1\%) could walk independently, 9 (39.1\%) with help or orthosis, and 2 (8.6\%) could not walk.

Table 2. Patients' mobility status, orthotic use, and rehabilitation program attendance 13 years ago and today.

\begin{tabular}{|l|l|l|}
\hline \multicolumn{2}{|l|}{$\begin{array}{l}13 \text { years ago } \\
\text { n (\%) }\end{array}$} & $\begin{array}{l}\text { Today } \\
\text { n (\%) }\end{array}$ \\
\hline Mobility & $15(38.4)$ & $20(51.2)$ \\
\hline Walking independently & $12(30.7)$ & $11(28.2)$ \\
\hline Walking with help/orthosis & $12(30.7)$ & $8(20.5)$ \\
\hline Not able to walk & $19(48.7)$ & $10(25.6)$ \\
\hline Orthosis & $20(51.2)$ & $29(74.3)$ \\
\hline Yes & & \\
\hline No & $39(100)$ & $23(58.9)$ \\
\hline Rehabilitation & 0 & $16(41.0)$ \\
\hline Yes & & \\
\hline No & &
\end{tabular}

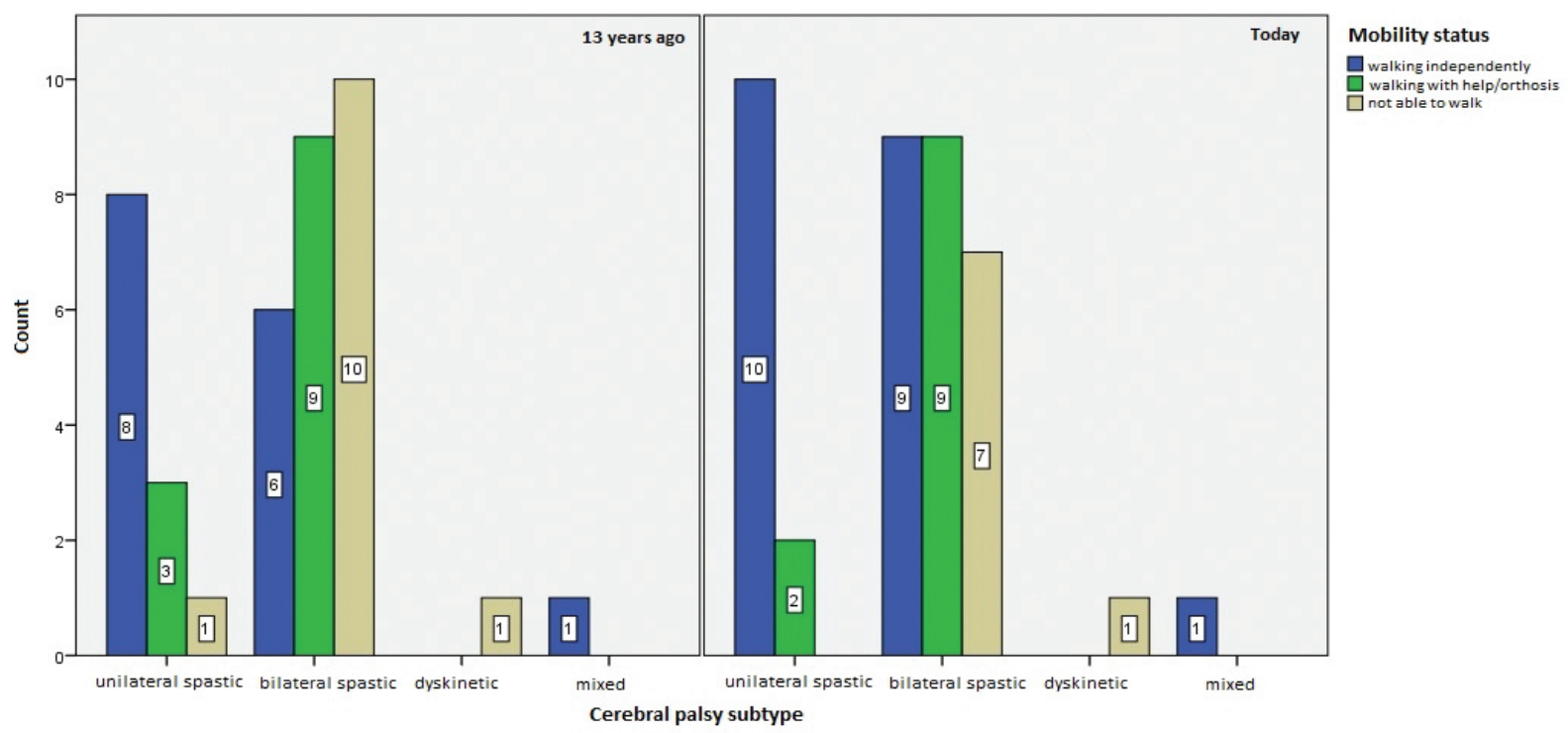

Figure 1. The distribution of participants' mobility status 13 years ago and today according to the cerebral palsy subtypes. 
Of the participants, 21 (48.8\%) were not followed by any CP-related doctors. Of the participants who continued their follow-up, 8 (18.6\%) were going for control once in 6 months, 10 (23.3\%) once a year, and 1 (2.3\%) with intervals of more than a year.

To evaluate their participation in life and independence in daily activities, their ability to participate in various activities was evaluated. The obtained data are shown in Table 3.

Of the participants, $10(23.3 \%)$ were able to go out independently and 30 (69.8\%) were involved in activities outside the home, regardless of being able to go independently. Of those dependent on home, 9 (20.9\%) did not go out, 16 (37.2\%) went out every day, 12 (27.9\%) went out once a week, and $2(4.7 \%)$ went out once a month.

The HRQoL was investigated using the EQ-5D-3L questionnaire. The index values (utility score) of the scale were calculated on the computer using the excel format prepared by the EuroQoL group based on the calculated formulas from different community samples. Utility score generally ranges from 0 (death) to 1 (perfect

\begin{tabular}{|c|c|c|}
\hline Activities & $\mathbf{n}$ & $\%$ \\
\hline \multicolumn{3}{|l|}{ TV remote } \\
\hline Yes & 26 & 60.5 \\
\hline No & 13 & 30.2 \\
\hline \multicolumn{3}{|l|}{ PC } \\
\hline Yes & 23 & 53.5 \\
\hline No & 16 & 37.2 \\
\hline \multicolumn{3}{|c|}{ Mobile phone } \\
\hline Yes & 21 & 48.8 \\
\hline No & 18 & 41.9 \\
\hline \multicolumn{3}{|c|}{ Dressing up } \\
\hline Yes & 17 & 39.5 \\
\hline No & 22 & 51.2 \\
\hline \multicolumn{3}{|l|}{ Toilet } \\
\hline Yes & 14 & 32.6 \\
\hline No & 25 & 58.1 \\
\hline \multicolumn{3}{|l|}{ Bathroom } \\
\hline Yes & 12 & 27.9 \\
\hline No & 27 & 62.8 \\
\hline \multicolumn{3}{|l|}{ Eating } \\
\hline Yes & 24 & 58.1 \\
\hline No & 14 & 32.6 \\
\hline
\end{tabular}

health). Turkish norm values were unavailable, thus the UK value set, which is in established use, was used as a reference in this study.

The mean index score was 0.36 \pm 0.42 . The mean EQVAS score was $68.4 \pm 24.01$. Index results according to variables and subdomain results are shown in Tables 4 and 5. The EQ-5D-3L mean index scores showed a statistically significant difference according to the CP subtype $(p<0.05)$, gender $(p<0.05)$, education status $(p<0.01)$, mobility status $(p<0.01)$, going out independently $(p<0.01)$, dressing up $(p<0.01)$, eating $(p<0.01)$, toilet $(p<0.01)$, and bath $(p<0.01)$.

\section{DISCUSSION}

This case-control study evaluated the current functional, social status, participation in healthcare and life, and HRQOL of individuals with CP who were followed 13 years ago. Additionally, rehabilitation, mobility, and orthosis usage were compared with the data 13 years ago.

The subtype distributions revealed that most of the participants have spastic bilateral $C P$, followed by spastic unilateral, dyskinetic, and mixed types, respectively. Adult tetraplegic and dyskinetic CP cannot reach advanced ages $^{16}$. This subtype distribution can be explained by the young average age of our participants (mean age 19.23) and the low rate of participants with mild disabilities applying to health care services.

Brodin and Fasth ${ }^{17}$ revealed that individuals with a motor disability have less opportunity to participate in social life than the general society. The literature, a 40-66\% rate of independent living and a 13-58\% rate of living with the family ${ }^{18,19}$. In this study, almost all of the participants lived with their families. Only one was married and living with his wife. Another study conducted in Turkey, similar to our study, revealed a very low independent living rate 3 .

The majority of the participants were illiterate and a high percentage of $(25.6 \%)$ special education. The number of individuals who completed compulsory education (primary and high school) was $30.7 \%$. Of them, one was a university graduate. Andersson and Mattsson ${ }^{18}$ revealed a $15 \%$ rate of compulsory school completion and $14 \%$ university graduate. The compulsory school completion rate of our participants is higher; however, our university completion rate is much lower.

The study conducted with the Netherlands CP registry revealed a $33 \%$ rate of employment ${ }^{20}$. Similarly, a study conducted with individuals with motor disabilities in Korea revealed a $34.2 \%$ employment rate ${ }^{21}$. However, the majority of our participants were unemployed. One was working part-time and one was working full-time. 


\begin{tabular}{|c|c|c|}
\hline & $\begin{array}{l}\text { Mean index } \\
\text { score }\end{array}$ & p-values \\
\hline \multicolumn{3}{|l|}{ CP subtype } \\
\hline Spastic unilateral & 0.64 & \multirow{4}{*}{$<0.05$} \\
\hline Spastic bilateral & 0.23 & \\
\hline Dyskinetic & -0.19 & \\
\hline Mixt & 1.00 & \\
\hline \multicolumn{3}{|l|}{ Gender } \\
\hline Male & 0.49 & \multirow{2}{*}{$<0.05$} \\
\hline Female & 0.19 & \\
\hline \multicolumn{3}{|l|}{ Education status } \\
\hline Illiterate & 0.04 & \multirow{6}{*}{$<0.01$} \\
\hline Literate & 0.86 & \\
\hline Special education & 0.27 & \\
\hline Primary school & 0.54 & \\
\hline High school & 0.75 & \\
\hline University & 0.85 & \\
\hline \multicolumn{3}{|l|}{ Working status } \\
\hline Unemployed & 0.33 & \multirow{3}{*}{$>0.05$} \\
\hline Part-time & 0.84 & \\
\hline Full-time & 1 & \\
\hline \multicolumn{3}{|l|}{ Mobility } \\
\hline Walking independently & 0.64 & \multirow{3}{*}{$<0.01$} \\
\hline Walking with help/orthosis & -0.11 & \\
\hline Not able to walk & -0.12 & \\
\hline \multicolumn{3}{|l|}{ Going out independently } \\
\hline Yes & 0.81 & \multirow{2}{*}{$<0.01$} \\
\hline No & 0.21 & \\
\hline \multicolumn{3}{|l|}{ Dressing up } \\
\hline Yes & 0.81 & \multirow{2}{*}{$<0.01$} \\
\hline No & 0.21 & \\
\hline \multicolumn{3}{|l|}{ Eating } \\
\hline Yes & 0.59 & \multirow{2}{*}{$<0.01$} \\
\hline No & -0.03 & \\
\hline \multicolumn{3}{|l|}{ Toilet } \\
\hline Yes & 0.76 & \multirow{2}{*}{$<0.01$} \\
\hline No & 0.14 & \\
\hline \multicolumn{3}{|l|}{ Bath } \\
\hline Yes & 0.81 & \multirow{2}{*}{$<0.01$} \\
\hline No & 0.17 & \\
\hline \multicolumn{3}{|c|}{ CP: Cerebral palsy, EQ-5D-3L: EuroQol 5-Dimension 3-Level } \\
\hline
\end{tabular}

Table 5. EQ-5D-3L questionnaire subdomain results.

\begin{tabular}{|l|l|}
\hline Dimension & $\begin{array}{l}\text { Number of } \\
\text { observations (\%) }\end{array}$ \\
\hline D1: Mobility & $5(11.6)$ \\
\hline No problem & $22(51.2)$ \\
\hline Moderate problem & $12(27.9)$ \\
\hline Severe problem & \multicolumn{2}{|l|}{} \\
\hline D2: Self-care & $8(18.6)$ \\
\hline No problem & $14(32.6)$ \\
\hline Moderate problem & $17(39.5)$ \\
\hline Severe problem & \multicolumn{2}{|l|}{} \\
\hline D3: Usual activities & $8(18.6)$ \\
\hline No problem & $18(41.9)$ \\
\hline Moderate problem & $13(30.2)$ \\
\hline Severe problem & \multicolumn{2}{|l|}{} \\
\hline D4: Pain/discomfort & $22(51.2)$ \\
\hline No problem & $16(37.2)$ \\
\hline Moderate problem & $1(2.3)$ \\
\hline Severe problem & $23(53.5)$ \\
\hline D5: Anxiety/depression & $12(27.9)$ \\
\hline No problem & $4(9.3)$ \\
\hline Moderate problem & \multicolumn{2}{|l}{} \\
\hline Severe problem & \\
\hline EQ-SD-3L: EuroQol 5-Dimension 3-Level \\
\hline
\end{tabular}

The findings revealed that the vast majority of the participants were illiterate and do not work and live with their families. This can be explained by the national family structure that takes care of people with disability at home and characterizes them as "not able to work." The high rate of non-working patients can also be explained by the limited employment opportunities. Employment is also an important issue as it creates an environment for social participation. In Turkey, we believe that various steps need to be taken to ensure education and participation in the social and business life of individuals with CP.

In Europe, the percentage of severe mental disorders in individuals with CP was $26-31 \%^{22,23}$. In our study population, the most common comorbidity was mental problems with a much higher incidence (69\%). A multicenter study conducted in Turkey revealed that the most common comorbidity was speech problems (32\%), followed by mental problems, epilepsy, and vision problems, respectively ${ }^{24}$. Cognitive problems, epilepsy, speech problems, and sensory problems are more common in our participants. Our sample may have high comorbidity; however, comorbidities, 
especially cognitive problems could not be objectively evaluated as the information was obtained from the relatives of patients over the phone. Relatives may have reflected the participants' conditions as worse than they were and patients with comorbidities may have been overestimated.

The proportion of those who could independently walk compared to 13 years ago was increased and the rate of wheelchair dependency was decreased. Andersson and Mattsson ${ }^{18}$ revealed that $35 \%$ of the participants had decreased walking ability and $9 \%$ stopped walking. However, they only included adult CP in their studies. The mean age of our sample was much lower. This improvement may be explained that some of the individuals may become functionally better in the natural development process in such a long time and also due to the greater potential for change in childhood.

However, orthotic usage significantly decreased over the past 13 years. The rates of our participants who continued rehabilitation programs also significantly decreased. Only approximately $60 \%$ continued rehabilitation. Additionally, only half of them were under regular doctor control. Most of the participants who came for control were under annual follow-up. During the rehabilitation process, which should continue throughout life, a large number of individuals with CP stop using orthotics, which is a restrictive treatment, disrupt rehabilitation programs, and do not come to regular doctor follow-up as time goes by. These results indicate that health authorities should strictly control the rehabilitation process whether they receive proper rehabilitation programs or not and ensure the accessibility of rehabilitation centers. Additionally, physiatrists should inform individuals with $\mathrm{CP}$ and caregivers about the importance of continuity of rehabilitation and offer different rehabilitation methods that encourage them to continue the rehabilitation program.

Only two of our participants who continued the rehabilitation program were unable to walk. Thus, the mobility of individuals who continued their rehabilitation program was better. This finding also shows the importance of lifelong rehabilitation.

The daily life activities of our participants were more successful in using the TV remote, computer keyboard, mobile phone, and eating. Most of them had problems in important daily activities, such as dressing up, toilet, and bathing. To ensure independence in their daily activities, increasing the number of ergotherapists that the physiatrists can work together in CP management is very important.
Approximately a quarter of our participants could independently go out. However, most of them were going out every day, even if they were not independent. Social integration is an important goal in CP. Our participants are dependent on their families; however, going out daily may partially demonstrate their participation in social life. From the activities that they can do, the use of mobile phones and computers may also show their participation in social life.

This study investigated HRQOL for CP using the EQ-5D-3L questionnaire. The mean index value for our sample was lower than the Swedish study result $(0.36 \text { and } 0.54 \text {, respectively })^{14}$. Our study obtained the information of participants from relatives using the proxy report form of EQ-5D-3L. However, Jarl et al. ${ }^{4}$ included only individuals who could respond. Therefore, they may include only functionally better participants in the study. Therefore, HRQoL index values may have a better result than our sample.

The mean of the Swedish population's EQ-VAS score was $80.2^{25}$. Our study revealed a 68.4 mean EQ-VAS score, which is much lower than the Swedish population reference value. Our value is compatible with the findings of Lundh et al. ${ }^{26}$.

HRQOL significantly varied according to gender, CP subtype, educational and working status, mobility, independent going out, and the ability to eat, dress up, go to the toilet, and bath. The findings of Jarl et al.${ }^{14}$ were also compatible with our study.

According to HRQoL subdomain analysis, self-care was the dimension that our participants had the most problems. Most of them have moderate problems in mobility and usual activities; however, most of them did not report any problems in terms of pain/discomfort and anxiety/depression. The studies of Jarl et al. ${ }^{14}$ revealed that the dimension with the highest problem was mobility (67\%) and pain/discomfort (61\%) and anxiety/ depression problem (54\%). Our participants were functionally limited; however, their social participation was high, which explains the low depression/anxiety ratio. However, these findings are explained by the difficulty in detecting mood and pain changes since most of our sample have mental problems.

One of our study limitations is the limited number of participants. Additionally, the caregivers' responses may not fully reflect the patient's true condition regarding the HRQoL and the activities that patients can do, as the information obtained cannot be directly obtained from the individual. Sociodemographic characteristics 
and QoL of the caregiver may also affect the child's QoL and participation. This study did not obtain detailed information about the caregiver. Therefore, a detailed sociodemographic evaluation of the caregiver is recommended in further studies.

\section{CONCLUSIONS}

This study is the first long-term follow-up study of $\mathrm{CP}$ that is conducted in a developing country, Turkey. The participation of individuals with $C P$ in social life and business life is quite limited. Orthosis usage and rehabilitation program attendance decrease with age. To increase the QoL of individuals with CP, it should be aimed to have an independent social life, work in a job, receive advanced education, and gain independence in daily life activities. Encouraging them to comply with goal-directed functional rehabilitation programs and regular follow-up evaluations is important to make the necessary interventions on time.

\section{Ethics}

Ethics Committee Approval: Research ethics approval was obtained from Istanbul Medeniyet University Goztepe Training and Research Hospital Clinical Research Ethics Committee (decision no: 2020/0025, date: 05.02.2020).

Informed Consent: All caregivers gave verbal informed consent.

Peer-review: Externally and internally peerreviewed.

\section{Author Contributions}

Concept: B.D.K., A.I., Design: B.D.K., A.I., Data Collection and/or Processing: B.D.K., A.I., Analysis and/ or Interpretation: B.D.K., A.I., Literature Search: B.D.K., A.I., Writing: B.D.K., A.I.

Conflict of Interest: The authors have no conflict of interest to declare.

Financial Disclosure: The authors declared that this study has received no financial support.

\section{REFERENCES}

1. Richards CL, Malouin F. Cerebral palsy: definition, assessment and rehabilitation. Handb Clin Neurol. 2013;111:183-95.

2. Blum RW, Garell D, Hodgman $\mathrm{CH}$, et al. Transition from childcentered to adult health-care systems for adolescents with chronic conditions. A position paper of the Society for Adolescent Medicine. J Adolesc Health. 1993;14:570-6.

3. İçağasıoğlu A, Doğruoz Karatekin B, Mesci E, Yumusakhuylu Y, Murat S, Yasin Ş. Assessment of adult patients with cerebral palsy. Turk J Phys Med Rehabil. 2020;66:429-35.
4. Murphy KP, Molnar GE, Lankasky K. Employment and social issues in adults with cerebral palsy. Arch Phys Med Rehabil. 2000;81:807-11.

5. Hutchison J. College students who have cerebral palsy. A followup study of employment. Cereb Palsy J. 1968;29:3-7.

6. Cohen P, Kohn JG. Follow-up study of patients with cerebral palsy. West J Med. 1979;130:6-11.

7. Alriksson-Schmidt Al, Ahonen M, Andersen $\mathrm{GL}$, et al. CP-North: living life in the Nordic countries? A retrospective register research protocol on individuals with cerebral palsy and their parents living in Sweden, Norway, Denmark, Finland and Iceland. BMJ Open. 2019;9:e024438.

8. Thomsen OS. Cerebral palsy in Denmark 1951. Acta Psychiatr Neurol Scand. 1954;29:55-6.

9. Rabin R, de Charro F. EQ-5D: a measure of health status from the EuroQol Group. Ann Med. 2001;33:337-43.

10. Dolan P. Modeling valuations for EuroQol health states. Med Care. 1997;35:1095-108

11. Mozzi A, Meregaglia M, Lazzaro C, Tornatore V, Belfiglio M, Fattore G. A comparison of EuroQol 5-Dimension health-related utilities using Italian, UK, and US preference weights in a patient sample. Clinicoecon Outcomes Res. 2016;8:267-74.

12. Kahyaoğlu Süt $H$, Unsar $S$. Is EQ-5D a valid quality of life instrument in patients with acute coronary syndrome? Anatol Cardiol. 2011;11:156-62.

13. Zhou T, Guan H, Yao J, Xiong X, Ma A. The quality of life in Chinese population with chronic non-communicable diseases according to EQ-5D-3L: a systematic review. Qual Life Res. 2018;27:2799-814.

14. Jarl J, Alriksson-Schmidt A, Rodby-Bousquet E. Health-related quality of life in adults with cerebral palsy living in Sweden and relation to demographic and disability-specific factors. Disabil Health J. 2019:12:460-6.

15. Bray N, Spencer LH, Edwards RT. Preference-based measures of health-related quality of life in congenital mobility impairment: a systematic review of validity and responsiveness. Health Econ Rev. 2020;10:9.

16. Himmelmann K, Sundh V. Survival with cerebral palsy over five decades in western Sweden. Dev Med Child Neurol. 2015;57: 762-7.

17. Brodin J, Fasth $\AA$. Habilitation, support and service for young people with motor disabilities. A Swedish perspective. Int J Rehabil Res. 2001;24:309-16.

18. Andersson C, Mattsson E. Adults with cerebral palsy: a survey describing problems, needs, and resources, with special emphasis on locomotion. Dev Med Child Neurol. 2001:43:76-82.

19. Kokkonen J, Saukkonen AL, Timonen E, Serlo W, Kinnunen P. Social outcome of handicapped children as adults. Dev Med Child Neurol. 1991;33:1095-100.

20. Michelsen SI, Uldall P, Hansen T, Madsen M. Social integration of adults with cerebral palsy. Dev Med Child Neurol. 2006;48:643-9.

21. Park SK, Yoon JY, Henderson T. Factors affecting employment among people with mobility disabilities in South Korea. Int J Rehabil Res. 2007;30:19-25.

22. No authors listed. Prevalence and characteristics of children with cerebral palsy in Europe. Dev Med Child Neurol. 2002;44:633-40. 
23. Nordmark E, Hagglund G, Lagergren J. Cerebral palsy in southern Sweden I. Prevalence and clinical features. Acta Paediatr. 2001;90:1271-6.

24. Yılmaz Yalçınkaya E, Hüner B, Dinçer U, Diraçoğlu D, Aydın R, İçağasıoğlu A. Demographic and Clinical Findings of Cerebral Palsy Patients in Istanbul: A Multicenter Study. Turk J Phys Med Rehabil. 2014;60:134-8.
25. Sun S, Irestig R, Burström B, Beijer U, Burström K. Health-related quality of life (EQ-5D) among homeless persons compared to a general population sample in Stockholm County, 2006. Scand J Public Health. 2012;40:115-25.

26. Lundh S, Nasic S, Riad J. Fatigue, quality of life and walking ability in adults with cerebral palsy. Gait Posture. 2018;61:1-6. 